\title{
An Analysis of the Impact of Financial Technology on the Development of Internet Finance
}

\author{
Jiahe Liu*, Shipu Huang \\ China Three Gorges University, Yichang 443002, Hubei Province, China. E-mail: 501206933@qq.com
}

\begin{abstract}
Nowadays, with the continuous development of modern technology, technologies such as blockchain, artificial intelligence and big data have promoted the rapid development and transformation of my country's traditional financial industry. From the traditional gold and silver standard and bank notes, to the rapid rise and development of electronic payment, mobile payment, digital currency and wealth management, China's Internet finance has achieved better and faster development. This article mainly studies the relative impact of fintech on the development of Internet finance, and aims to make better use of fintech for financial management, to promote the better execution efficiency of financial-related circulation, and to promote the development of China's financial industry, which is also more informatized, modernized and intelligent.
\end{abstract}

Keywords: Fintech; Internet Finance; Development; Impact

In the era of Internet information, the traditional financial industry has been gradually replaced by the continuous development of technologies such as artificial intelligence, big data, and the Internet, which has subverted the development of the traditional financial industry to a certain extent and promoted the rapid development of financial technology. In just a few years, people's financial management and payment methods have gradually changed from paper money and other forms to electronic money and mobile payment. At the same time, they have gradually changed the way of life and promoted the sustainable and healthy development of the financial economy.

\section{The concept and connotation of financial technology}

The so-called financial technology is mainly a new product service, new technology application and emerging business model that has the most cutting-edge technologies such as artificial intelligence, cloud computing, blockchain and big data, which have a great impact on the financial services business and financial market. Through the application of various scientific and technological means, it innovates the services and products provided by the traditional financial industry, promotes its operating costs to be effectively reduced, and improves its operating efficiency.

With the rapid development of scientific information technology, fintech has the characteristics of mixed industry, fast and rapid change, etc. Through the effective integration of cutting-edge technologies such as artificial intelligence technology, blockchain and big data and traditional financial service business or products, it has been continuously derived blockchain finance, artificial intelligence finance and big data finance.

The rapid development of financial technology can better safeguard China's financial security, help financial industry to "overtake on a bend", realize the livelihood inclusiveness, and promote the better construction and develop-

Copyright (C) 2020 Jiahe Liu and Shipu Huang

doi: $10.18282 /$ ff.v9i2.897

This is an open-access article distributed under the terms of the Creative Commons Attribution Non-Commercial License

(http://creativecommons.org/licenses/by-nc/4.0/), which permits unrestricted non-commercial use, distribution, and reproduction in any medium,

provided the original work is properly cited. 
ment of the "Belt and Road".

\section{Analysis of the relative impact of fintech on the development of Internet finance}

Since the composition of financial technology is mainly big data, artificial intelligence and blockchain technology, then in terms of the impact of Internet finance development, analysis and discussion are mainly from these three aspects:

\subsection{The impact of big data on the development of Internet finance}

Big data technology is an important content and component of financial technology, and it plays a very important role in promoting the development of financial technology. Currently, big data financial management, lending and insurance are closely related to people's lives. The well-known big data financial management mainly includes the funds in Ant Wealth, Yu'ebao, Yulibao, WeChat's small change, etc., which can bring great convenience to people's wealth management through Internet technology. At the same time, in the Internet lending market, through the development of Internet technology, data can be more accurately collected and applied, and people's needs, preferences, personal conditions, age, and even ID card information can be more accurately mastered ${ }^{[1]}$. It can not only better grasp people's credit situation, but also provide more financial services for customers. For example, people currently use borrowing, flowering, etc. Alipay will control the risk of borrowing based on the customer's financial and economic conditions and personal credit status, and strive to provide customers with more convenient conditions and services. There will also be many other online loan platforms on the Internet that provide lending services, which has tested human morality to a certain extent, and also curbed the occurrence of moral hazard. In addition, with the rapid development of modern technology, the development trend of insurance is gradually becoming more informationized, modernized, and intelligent. People can match personal insurance plans through big data technology, and each family can be funded through the input of related data. Dynamic configuration of the status, basic information and relevant members' conditions, and recommend some matching insurance packages or solutions ${ }^{[2]}$. People can apply and purchase online through the Internet without intervention of insurance salespersons and agents. To a certain extent, it has also promoted the rapid development of Internet finance.

\subsection{The impact of artificial intelligence on the development of Internet finance}

The impact of artificial intelligence on Internet finance is mainly reflected in service experience and intelligent financial management. From the perspective of service experience, under the background of continuous development of artificial intelligence technology, cash access, transfer and other functions have replaced manual, and these functions can be realized through automatic deposit and withdrawal machines and bank APPs ${ }^{[3]}$. At the same time, many banks have realized the electronic and information processing of bank card-related business, which can be handled by themselves without manual operation, which saves manpower costs to a certain extent. At the same time, with the rapid development of face recognition technology, many financial services can be quickly realized through face recognition, and many services can be achieved through the Internet or smart APP at home, without having to go to the business premises for business processing, which has facilitated people's work and life, and has also promoted Internet finance to become more intelligent and information-based. In addition, in terms of intelligent wealth management, many people will purchase wealth management products through the mobile banking APP, and also test their investment preferences to guide customers to rational wealth management, and recommend some wealth management products suitable for customers to improve the service level of intelligent financial management ${ }^{[4]}$.

\subsection{The impact of blockchain on the development of Internet finance}

In the field of Internet finance, blockchain technology can protect intellectual property rights, effectively build commercial agreements, and improve the digital currency system ${ }^{[5]}$. The use of blockchain technology can enable 
Europe to clearly grasp the flow of each fund, to a certain extent, it can contain the risk of misappropriation of funds ${ }^{[6]}$. At the same time, with the development of blockchain technology, people's assets are gradually securitized, and many investment transactions will be recorded on the blockchain, which can facilitate transactions ${ }^{[7]}$, and can also quickly distribute assets, capital flows, etc. ${ }^{[8]}$ Viewing has greatly promoted the rapid development of Internet finance ${ }^{[9]}$.

\section{Conclusion}

In summary, with the continuous development of intelligence, informatization, and modernization, Internet technology has subverted the development model of the traditional financial industry and has caused great changes in all aspects of people's lives. The rapid development of technologies such as artificial intelligence, blockchain and big data has a very important role in promoting the development of my country's Internet financial industry.

\section{References}

1. Wang X. The enlightenment of British supervision sandbox on my country's Internet financial supervision in the era of financial technology (in Chinese). Social Science Journal of Harbin Normal University 2018; 9(5): 85-87. doi: 10.3969/j.issn.2095-0292.2018.05.021.

2. Chen J. Status of Internet finance and fintech development (in Chinese). Cooperative Economy and Technology 2020; (1): 23-24.

3. Zhang Y, Gao W. Self-construction, cultural differences and credit risk: Empirical evidence from Internet finance (in Chinese). Finance and Economics Research 2020; (1): 12-14.

4. Wang X. Telecommunication Internet technology finance helps the ecological development of retail industry (in Chinese). Fortune Today 2019; (7): 30.

5. Zhang N, Zhang J. Analysis of the problems and countermeasures of Internet financial risk supervision (in Chinese). Private Technology 2017; (1): 203. doi: 10.3969/j.issn.1673-4033.2017.01.190.

6. Ding H. Research on the impact of Internet finance development on the efficiency level of my country's commercial banks. Kunming: Yunnan University of Finance and Economics; 2020. p. 141-143.

7. Zhang Z. Analysis of the problems and countermeasures in the development of big data finance (in Chinese). Commercial Economy 2020; 6-8.

8. Zhang $\mathrm{X}$, Zhao $\mathrm{H}$. On the universal financial education for college students under the background of Internet finance development (in Chinese). Chinese and Foreign Entrepreneurs 2020; 26-29.

9. Yang X. On the influence of Internet finance on commercial banking business (in Chinese). Commercial News $2019 ; 38-41$. 